\title{
Co-digestion of Poultry Sludge Filter Pressed Cake with Market Waste to Enhance the Compost Quality
}

\author{
SC Wijesekara ${ }^{1}$, C Malwana $^{2}$, WBMAC Bandara ${ }^{1}$, and GY Jayasinghe ${ }^{1 *}$
}

\begin{abstract}
Huge quantities of market waste (MW) materials are generated yearly in Sri Lanka as organic waste and, in present, composting is regarded as one of the sustainable technique in waste management. The removal of solid waste is the last operation of solid waste management. Currently, the wastewater treatment plant of "Nelna" farm in Gampaha, Sri Lanka has been generating almost one tonne of poultry sludge filter pressed cake (PSFC) per day as a waste from the poultry industry. While the unsystematic disposal of PSFC may cause not only air pollution and bad odor but also nutrient pollution of ground waters and inland water bodies, compost research studies were conducted as one of the environmentally acceptable methods for recycling several types of sludge. Co-digestion was studied in order to discover the optimum mixing ratio of PSFC and MW for improved quality compost production. Four different types of treatments were prepared with three replicates by mixing PSFC and MW at the rates of; (T1) $0 \%$ PSFC + 100\% MW, (T2) $25 \%$ PSFC + 75\% MW, (T3) $50 \%$ PSFC + $50 \% \mathrm{MW}$ and (T4) $75 \%$ PSFC $+25 \%$ MW respectively. Physical and chemical characteristics of developed composts were analyzed after 10 weeks.

Treatment (T2) with 25\% PSFC $+75 \%$ MW reported the optimum physical and chemical properties with reference to standard compost. Bulk density, true density, moisture content, mean weight diameter and coarseness index of the treatment with $25 \%$ PSFC $+75 \%$ MW were $0.41 \mathrm{gcm}^{-3}, 1.42 \mathrm{gcm}^{-3} 24.35 \%, 0.054$ $\mathrm{mm}$ and $32.2 \%$, respectively. Furthermore, electrical conductivity, $\mathrm{pH}$, organic carbon, nitrogen, phosphorous, potassium and $\mathrm{C}: \mathrm{N}$ ratio of the above treatment $(25 \%$ PSFC $+75 \% \mathrm{MW})$ were $5.61 \mathrm{dS} / \mathrm{m}$, $7.5,24.17 \%, 2.45 \%, 0.54 \%, 1.8 \%$, and 9.8 , respectively.
\end{abstract}

Keywords - compost, co-digestion, filter cake, market waste.

\section{INTRODUCTION}

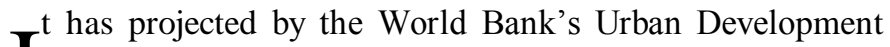
Department, that the quantity of municipal solid wastes (MSW) generation will rise from the current 1.3 billion tons per year to 2.2 billion tons per year by 2025. With escalating urbanization, waste problems have become very significant [1] in rapidly growing cities in developing countries. The yearly, global cost of this indispensable solid waste management is projected to increase from the current $\$ 205$ billion to $\$ 375$ billion and this cost is increasing most

\footnotetext{
${ }^{1}$ Department of Agric. Engineering, Faculty of Agriculture, University of Ruhuna, Mapalana, Sri Lanka

${ }^{2}$ Central Environmental Authority, Maligawatta, Kirindiwela, Gampaha, Sri
}

severely for those cities in low income countries [2]. When consider Sri Lanka, solid wastes management is an integral part of the urban Environment as it deals with the large quantities of annual market waste (MW) production. Landfills, incineration, recovery and recycling, plasma gasification and composting are proper waste management methods that are practicing in the world.

At present, composting has gained much attention in waste management practices rather than disposal of solid wastes into landfills. Because, composting not only reduces the amount of waste that needs to be disposed but also converts it into fertile compounds that can be used for gardening, landscaping or house plants. Natural ecosystems have been proven composting is an efficient eco-friendly method of breaking down organic materials into a valuable product.

As animal protein has become increasingly imperative in Sri Lankan food industry over the past decade, Sri Lankan poultry production also has increased in last few years, while it simultaneously has resulted in high amount of waste generation. And the indiscriminate disposal of PSFC can cause air pollution and bad odor as well as nutrient pollution of ground and inland water bodies. "Nelna" is one of the major poultry producing large-scale companies in Gampaha, Sri Lanka. The wastewater, effluent and sludge treatment plant of "Nelna" farm daily produce one tonne of filter pressed cake (PSFC) due to high producing capacity [3]. Currently, the only waste management method practicing by "Nelna" farm for the disposal of filter pressed cake is the burial of them in coconut lands in Gampaha area.

When consider about composting of Municipal Solid Wastes solely, the resulting compost mixture has high percentage of sand concentration and poor fertilizer ability. Because of that, the improvement of compost quality is very essential, and it will support to popularize the urban agriculture as well. Consequently, this study was carried out to find out quality compost production by mixing municipal solid waste and poultry sludge filter pressed cake at the compost plant conducted by the Central Environment Authority in Dompe Municipal Council, Gampaha, Sri Lanka.

Co-digestion is the simultaneous digestion of two or more organic waste feedstocks and it has been figured out that the use of co-substrates usually improves the compost quality from anaerobic digester due to positive synergisms 
established in the digestion medium and the supply of missing nutrients by the co-substrates [4].

Therefore, the main objective of this study was to determine the optimum mixing ratio of poultry sludge filter pressed cake (PSFC) and market waste (MW) for quality compost production.

\section{MethodOLOGY}

The research was conducted in "Green Park" sanitary land fill site, Kirindiwela, Gampaha, Sri Lanka, managed by the Central Environmental Authority. The market waste (MW) and poultry sludge filter pressed cake (PSFC), used in this experiment were collected from Dompe market and "Nelna" poultry farm located in Gampaha, Sri Lanka, respectively.

Compost studies were conducted as one of the environmentally acceptable methods for recycling many types of sludge. Co-digestion was studied in order to find out the optimum mixing ratio between PSFC and MW for better quality compost production. The experimental design was completely randomized design with three replicates and all the treatment piles were arranged randomly. Treatment ratios were prepared by wet weight basis and all the treatments were replicated three times. Four different types of treatments were used in the experiment is given by the Table I

TABLE I: Different types of treatments used in the experiment

\begin{tabular}{cc}
\hline \hline Treatments & Composition \\
\hline $\mathrm{T} 1$ & $0 \% \mathrm{PSFC}+100 \% \mathrm{MW}$ \\
$\mathrm{T} 2$ & $25 \% \mathrm{PSFC}+75 \% \mathrm{MW}$ \\
$\mathrm{T} 3$ & $50 \% \mathrm{PSFC}+50 \% \mathrm{MW}$ \\
$\mathrm{T} 4$ & $75 \% \mathrm{PSFC}+25 \% \mathrm{MW}$
\end{tabular}

PSFC: poultry sludge filter pressed cake, MW: Market waste Preparation of market wastes

The waste sample was collected from waste transporting tractors and compactors. Unwanted materials for composting such as plastic, polythene, Styrofoam, glass, steel, E waste, high moisture vegetables and etc. were sorted out. Sorted waste was homogenized by mixing.

TABLE II: composition of poultry sludge filter pressed cake

\begin{tabular}{ll}
\hline \hline Parameter & $\%$ \\
\hline Moisture & 65 \\
Ash & 6.3 \\
Organic carbon & 7 \\
$\mathrm{pH}(1: 10)$ at $28.3^{\circ} \mathrm{C}$ & 8 \\
Sulphur $(\mathrm{S})$ & 0.1 \\
Total Phosphorous $\left(\mathrm{P}_{2} \mathrm{O}_{5}\right)$ & 1 \\
Total Potassium & 1.1 \\
Total Kjeldhal Nitrogen & 0.9 \\
\hline \hline
\end{tabular}

\section{Preparation of filter pressed cake}

The semi solids sludge sample was collected from wastewater treatment plant of "Nelna" farm, Gampaha. The moisture percentage was $65 \%$. Transported cake stored on cement floor for 2 hours under sunshine to reduce moisture content. Optimum moisture percentage was obtained by squeezing method. The main characteristics of the filter pressed cake are shown in Table II.

\section{Compost piles preparation}

Bed layout was drawn on the concrete floor by using marker as $1 \mathrm{~m}$ length and $1 \mathrm{~m}$ width. Treatment ratios (Table II) were prepared by wet weight basis. Using weight balance market waste and filter pressed cake were weighted and mixed well for homogenous mixture. All treatments were replicated three times and all 12 piles were kept at $1 \mathrm{~m}$ height and spacing of $0.3 \mathrm{~m}$. All piles were labeled with a pile number and a treatment number.

The constructed beds were evaluated for several characters and turned once in six days' intervals. All beds were mixed in the same day and water was added to increase moisture up to required level. Temperature was recorded in each and every day. For each reading, three locations in each compost pile were monitored with a $30 \mathrm{~cm}$ in length probe. Samples for the analysis were collected from each bed just after turning. Each sample was a mixture of four subsamples taken from different points along the pile.

After two months the constructed compost beds were sieved separately and evaluated for several physical and chemical parameters such as temperature, $\mathrm{pH}, \mathrm{EC}$, moisture content (MC), organic carbon (OC), total $\mathrm{N}, \mathrm{C}: \mathrm{N}$ ratio, phosphorus, true density (TD), bulk density (BD) and particle size distribution.

\section{Statistical Analysis}

Obtained data were subjected to the analysis of variance to determine the treatment effects. Duncan's multiple comparison range test was used to determine whether there a significant difference exists or not between the means using SAS package.

\section{RESUlTS AND DisCUSSION}

\section{Temperature variation}

Results of temperature measurements of compost piles are shown in Figure I. Temperature measurements of the compost piles were within the range of $28.6-61.7{ }^{\circ} \mathrm{C}$ and it was typical to the standard temperature variation in a composting process. Temperature variation of the compost depends on its existing phases which are mesophilic, thermophilic and cooling phases. Temperature ranges are $10-40{ }^{0} \mathrm{C}, 40-60{ }^{0} \mathrm{C}$ and $40-10{ }^{0} \mathrm{C}$ in mesophilic phase, thermophilic phase and cooling phase, respectively [5]. When the sludge content was increasing in the treatment, high temperature variation was observed within 24 hours at the start of the composting process. Temperatures were dropped from $2^{\text {nd }}$ week to $4^{\text {th }}$ 
week due to high moisture content. Constant temperature values were reported at the mature stage.

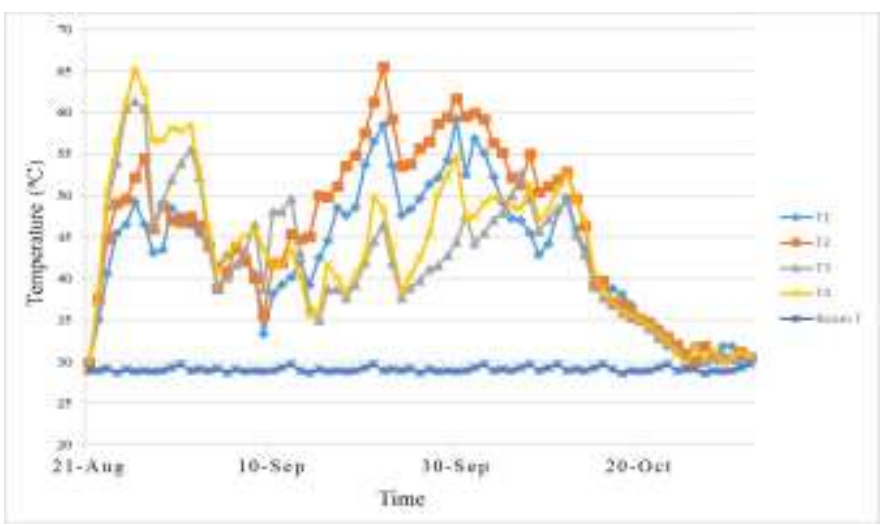

Figure I: Temperature variation of compost piles

\section{Moisture content Variation}

Moisture content of compost piles varied in between 24.03$27.23 \%$ during the composting process and its variation has shown by Figure II. There was no significant difference between $\mathrm{T}_{1}$ and the $\mathrm{T}_{2} . \mathrm{T}_{3}$ and $\mathrm{T}_{4}$ were not significantly different from each other. Ideal moisture level is less than $25 \%$ [6]. $\mathrm{T}_{1}$ and $\mathrm{T}_{2}$ showed low moisture levels compared to the $\mathrm{T}_{3}$ and $\mathrm{T}_{4}$ and they were in the range of ideal moisture level.

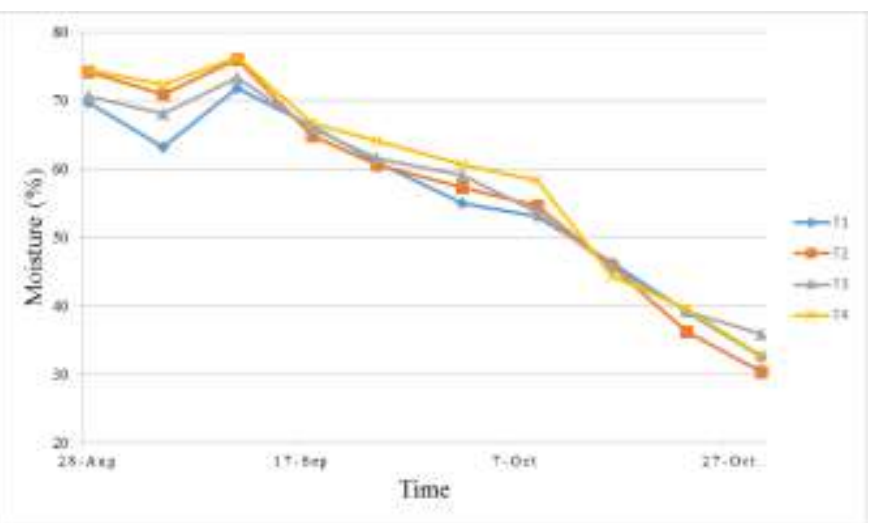

Figure II: Moisture variation during compost process

TABLE III: PHYSICAL PROPERTIES OF FINAL COMPOST SAMPLES

\begin{tabular}{cccc}
\hline \hline Treatments & $\mathrm{BD}\left(\mathrm{gcm}-{ }^{3}\right)$ & $\mathrm{TD}\left(\mathrm{gcm}^{-3}\right)$ & $\begin{array}{c}\text { MWD } \\
(\mathrm{mm})\end{array}$ \\
\hline $\mathrm{T} 1$ & $0.40 \mathrm{a}$ & $1.39 \mathrm{a}$ & $0.05 \mathrm{a}$ \\
$\mathrm{T} 2$ & $0.41 \mathrm{a}$ & $1.42 \mathrm{a}$ & $0.05 \mathrm{a}$ \\
$\mathrm{T} 3$ & $0.43 \mathrm{~b}$ & $1.56 \mathrm{~b}$ & $0.04 \mathrm{~b}$ \\
$\mathrm{~T} 4$ & $0.45 \mathrm{c}$ & $1.59 \mathrm{~b}$ & $0.04 \mathrm{c}$ \\
\hline \hline
\end{tabular}

BD; Bulk density, TD; True density, MWD; Mean weight diameter, (Means followed by the different letters in the same column differed significantly according to Duncan's multiple range test $(\mathrm{P}=<0.05)$.

Bulk density provides good indicator of compost. It determines the air pores and physical structure. Bulk density (Table III) values of the final compost samples were increased with the increase of PSFC volume. This is because, when the particle size is small, mass compaction is higher in unit volume and then the bulk density value is normally increased [6]. T1 and T2 were closer to the ideal value of less than 0.40 $\mathrm{gcm}^{-3}$ [7] while T4 showed the highest bulk density value.

All treatments and control pile samples were within the range of ideal particle density (Table III) limit for compost of $1.4-2.0 \mathrm{gcm}^{-3}$ [8] while the highest value was reported in T4 which is a $12 \%$ increment compared to the control (T1).

When the sludge content was increased in the treatment, mean weight diameter (MWD) has decreased while the T4 treatment gave the lowest MWD (Table III).

TABLE IV: PARTICLE SIZE DISTRIBUTIONS OF DIFFERENT COMPOST SAMPLE

\begin{tabular}{lllll}
\multicolumn{5}{c}{ (AS A \%) } \\
\hline \hline Treatments & $\mathrm{T}_{1}$ & $\mathrm{~T}_{2}$ & $\mathrm{~T}_{3}$ & $\mathrm{~T}_{4}$ \\
\hline$>1.7$ & 12.66 & 11.82 & 10.35 & 9.27 \\
$1.7-1.0$ & 11.55 & 2.43 & 17.29 & 15.32 \\
$1.0-0.5$ & 44.95 & 45.55 & 59.46 & 59.56 \\
$0.5-0.35$ & 11.60 & 10.37 & 9.31 & 10.99 \\
$0.35-0.25$ & 3.38 & 6.67 & 2.60 & 2.54 \\
$0.25-0.18$ & 0.64 & 2.80 & 0.95 & 1.53 \\
$0.18-0.1$ & 0.10 & 1.42 & 0.27 & 0.46 \\
$0.1-0.075$ & 0.01 & 0.92 & 0.12 & 0.30 \\
$<0.07$ & 0 & 0.285 & 0.07 & 0.21 \\
CI $(\%)$ & 39.21 & 16.10 & 13.82 & 12.29 \\
\hline \hline
\end{tabular}

CI: Coarseness Index

The particle size distribution (Table IV) of particles is very important because of the size of the pores determines the movement and the distribution of water and air in the media [9]. According to [10], particle fraction smaller than $0.5 \mathrm{~mm}$ (in particular between 0.1 and $0.25 \mathrm{~mm}$ ) has the highest influence on porosity and water retention while excess of fines (less than $0.1 \mathrm{~mm}$ ) clog pores, increases non plant available water holding capacity and decreases air filled porosity.

Coarseness index (CI) is the cumulative volume percentage of particles greater than $1 \mathrm{~mm}$ [11]. The ideal CI of compost should be in the range of $30-45 \%$. T1 and T2 treatments showed higher CI percentages and they were in the ideal range while T3 and T4 treatments showed low CI (Table IV) percentages and they were not in the ideal range.

TABLE V: Chemical properties of final compost samples

\begin{tabular}{lllll}
\hline \hline & $\mathrm{T}_{1}$ & $\mathrm{~T}_{2}$ & $\mathrm{~T}_{3}$ & $\mathrm{~T}_{4}$ \\
\hline $\mathrm{pH}$ & $7.50 \mathrm{a}$ & $7.55 \mathrm{a}$ & $7.54 \mathrm{a}$ & $7.45 \mathrm{a}$ \\
$\mathrm{EC}(\mathrm{ds} / \mathrm{m})$ & $4.16 \mathrm{a}$ & $5.61 \mathrm{~b}$ & $6.70 \mathrm{c}$ & $6.77 \mathrm{c}$ \\
$\mathrm{OC}\left(\mathrm{gkg}^{-1}\right)$ & $203.81 \mathrm{c}$ & $241.84 \mathrm{a}$ & 225.25 & $232.83 \mathrm{a}$ \\
$\mathrm{N}\left(\mathrm{gkg}^{-1}\right)$ & $15.21 \mathrm{~d}$ & $24.56 \mathrm{c}$ & $25.93 \mathrm{~b}$ & $27.14 \mathrm{a}$ \\
$\mathrm{P}\left(\mathrm{gkg}^{-1}\right)$ & $4.65 \mathrm{a}$ & $5.41 \mathrm{~b}$ & $4.95 \mathrm{a}$ & $5.34 \mathrm{~b}$ \\
$\mathrm{~K}\left(\mathrm{gkg}^{-1}\right)$ & $16.92 \mathrm{~b}$ & $18.35 \mathrm{a}$ & $15.87 \mathrm{c}$ & $12.62 \mathrm{~d}$ \\
$\mathrm{C} / \mathrm{N}$ & $13.39 \mathrm{a}$ & $9.846 \mathrm{~b}$ & $8.68 \mathrm{c}$ & $8.57 \mathrm{c}$ \\
\hline \hline
\end{tabular}

EC; Electric conductivity, OC; organic carbon, N; Nitrogen, P; Phosphorous, $\mathrm{K}$; Potassium, (Means followed by the different letters in the same row differed significantly according to Duncan's multiple range test $(\mathrm{P}=$ or $<0.05)$. 
Table V shows the variation of $\mathrm{pH}$ of compost piles during the composting process. $\mathrm{pH}$ values were varied in between $6.50-8.25$. Highest $\mathrm{pH}$ values of the compost were shown during $5^{\text {th }}$ week from the start and it may be due to the accumulation of ammonia compounds in composting materials by the process of protein decomposition [12]. According to Table $\mathrm{V}$, $\mathrm{pH}$ values of final out put varied from 7.45-7.55. There was no significant difference between treatments and controls. According to the Sri Lankan standards acceptable $\mathrm{pH}$ range for the compost is $6.5-8.5$ [6]. All treatments and control piles were within the ideal range.

Electrical conductivity expresses the soluble salt levels in the compost. $\mathrm{Na}, \mathrm{K}, \mathrm{Cl}$, ammonia and sulfate ions mainly contribute for salinity [12]. Electrical conductivity of compost piles varied in between $5.61-11.8 \mathrm{ds} / \mathrm{m}$ during the composting process. There was no significant difference between $T_{3}$ and $T_{4}$ according to the results shown by Table $V$. Other treatments were significantly differed from others. Final EC varied in between $4.16-6.77 \mathrm{ds} / \mathrm{m}$. Ideal level of EC is less than $4 \mathrm{ds} / \mathrm{m}$ [13]. $\mathrm{T}_{1}, \mathrm{~T}_{2}, \mathrm{~T}_{3}$ and $\mathrm{T}_{4}$ exceeded the suggested acceptable limit. $\mathrm{T}_{1}$ showed EC value of $4.16 \mathrm{ds} / \mathrm{m}$, which is not much higher than that of ideal vale.

Organic carbon levels of compost piles were varied in between $203-645 \mathrm{gkg}^{-1}$ during the composting period (Table V). Final organic carbon content varied in between 203.8 $232.8 \mathrm{gkg}^{-1}$. There was no significant difference between $\mathrm{T}_{2}$ and $\mathrm{T}_{4}$, but all other treatments were significantly differed from each other (Table V). $T_{2}$ value is higher than that of $T_{4}$. Lowest organic carbon level was given by the $T_{1}$. All 3 treatments were significantly higher than the control.

Nitrogen levels were obtained only from the final compost samples. Nitrogen levels were varied in the range of $15.2-$ $25.9 \mathrm{gkg}^{-1}$. There were significant differences among all treatments (Table V). Ideal level of nitrogen is $10 \mathrm{gkg}^{-1}(1 \%)$ [6]. $\mathrm{T}_{4}$ gave the highest $\mathrm{N} \%$ and $\mathrm{T}_{1}$ gave the lowest value. The $\mathrm{N}$ content in all treatments were higher than the $\mathrm{T}_{1}$.

Phosphorous is a critical element in plant $[14,15,16]$. Phosphorous containing compounds are involved in energy capture during photosynthesis, carbohydrate metabolism, protein and nucleic acid synthesis. Phosphorous is absorbed into plant in the form of phosphates through an energy requiring process $[14,15,16,17]$. Phosphorous levels varied in between 4.6-5.4 $\mathrm{gkg}^{-1}$. There were no significant differences between the $T_{1}$ and treatment $T_{3}$. There were no significant differences between treatments $\mathrm{T}_{2}$ and $\mathrm{T}_{4}$ (Table V). Ideal level of potassium should be $5 \mathrm{gkg}^{-1}$ [6]. Highest phosphorous value $5.4 \mathrm{gkg}^{-1}$ was obtained by $\mathrm{T}_{2}$ and control showed the lowest value of $4.6 \mathrm{gkg}^{-1}$.

All treatments were significantly different from each other (Table V). When SFC increasing in treatments, the potassium level has been decreased. Potassium levels of final compost samples varied in between $12.62-18.35 \mathrm{gkg}^{-1}$. The highest potassium level and the lowest potassium levels were obtained from $T_{2}$ and $T_{4}$, respectively. Ideal level of potassium is 10 $\mathrm{gkg}^{-1}$ [6]. All treatments were higher than the ideal potassium level.
The C:N Ratio is widely used as an indicator of the maturity and stability of organic matter [18,19]. According to Sri Lankan standards the carbon to nitrogen ratio of the final compost should be in the range of 10 to 25 . C: $\mathrm{N}$ ratio of tested compost samples varied in between 8.57-13.39 (Table V). Highest and lowest $\mathrm{C}: \mathrm{N}$ ratios were obtained from $\mathrm{T}_{1}$ and $\mathrm{T}_{4}$ respectively. Low C:N ratios were observed when the sludge content was increasing.

\section{CONCLUSION}

It can be concluded that, in general, the treatments elaborated with PSFC and MW showed suitable physical and chemical properties. Among them, treatment with $(25 \%$ PSFC $+75 \%$ MW) showed optimum physical and chemical properties compared to the standard compost. Bulk density, true density, moisture content, mean weight diameter and coarseness index of treatments with (25\% PSFC $+75 \% \mathrm{MW})$ were $0.4 \mathrm{gcm}^{-3}, 1.42 \mathrm{gcm}^{-3} 24.35 \%, 0.054 \mathrm{~mm}$ and $32.2 \%$ respectively. In addition, electrical conductivity, $\mathrm{pH}$, organic carbon, nitrogen $(\mathrm{N})$, phosphorous $(\mathrm{P})$, potassium $(\mathrm{K})$, and $\mathrm{C}$ : $\mathrm{N}$ ratio of the treatment with (25\% PSFC $+75 \% \mathrm{MW})$ were $5.61 \mathrm{dS} / \mathrm{m}, 7.5,24.17 \%, 2.45 \%, 0.54 \%, 1.8 \%$, and 9.8 , respectively. Therefore, co-digestion of PSFC with MW can be considered as a proper method of disposing generated PSFC and the treatment with of $25 \%$ PSFC $+75 \% \mathrm{MW}$, is the optimum ratio for better quality compost production by using PSFC and MW.

\section{REFERENCES}

[1] J. Tai, W. Zhang, Y. Che and D. Feng, "Municipal solid waste sourceseparated collection in China, a comparative analysis," Waste Manage, vol. 31, p. 2011. http://dx.doi.org/10.1016/j.wasman.2011.03.014

[2] Hoornweg D, and Bhada-Tata P., " What is a Waste: A Global Review of Solid WasteManagement",15, 116-120, 1998.

[3] Nelna farm waste treatment plant annual report, "Annual wastewater treatment report," 2015.

[4] R. Alvarez and G. Liden, "Semi-continuous co-digestion of solid slaughterhouse waste,manure, and fruit and vegetable waste," Renewable $\begin{array}{lllll}\text { Energy, } & \text { vol. } \quad 33, \quad \text { pp. } & 726-734, & 2000 .\end{array}$ http://dx.doi.org/10.1016/j.renene.2007.05.001

[5] Gomez, A., "The evaluation of compost quality, Trends in analytical chemistry", 17, 310-314, 1998.

[6] SLS, "Sri Lankan Standards," Technical guidelines on solid waste management Sri Lanka, pp. 42-57, 2012.

[7] C. Corti, L. crippa, P. Genevini, L and M. Centemero, "Compost use in plant nurseries: hydrological and physicochemical characteristics," Compost science, vol. 6, pp. 35-45, 1998.

[8] M. Abad, F. Fornes, C. Carrion, V. Noguera, P. Noguera and A. Maquieira, "Physical properties of various coconut coir dust compared to peat," HortScience, vol. 40, pp. 2138-2144, 2005.

[9] M. Raviv, Y. Chen and Y. Inbar, "Peat and peat substitutes as growth media for container- grown plants,"The role of organic matter in modern agriculture, vol. 34, pp. 257-287, 1986. http://dx.doi.org/10.1007/978-94-009-4426-8_11

[10] K. A. Hendreck, "Properties of coir dust, and its use in the formulation of soilless potting media," SoilSci. Plant Anal, vol. 24, pp. 115-142, 1993.

[11] D. Richards, M. Lane and D. V. Beardsell, "The influence of particle size distribution in pinebark:sand:brown coal plotting mixes on water supply, aeration and plant growth," Sci. Hortic., vol. 29, pp. 1-14, 1986. http://dx.doi.org/10.1016/0304-4238(86)90025-7

[12] P. Noguera, M. Abad, P. R. A. Maquieira and V. Noguera, "Influence of particle size on physical and chemical properties of coconut coir dust as a container medium," Commun soil science plant anal, vol. 34, pp. 593605, 2003.http://dx.doi.org/10.1081/CSS-120017842 
[13] Abad, M., Noguera, P., Bures, S., "National inventory of organic wastes for use as growing media for ornamental potted plant production: Case study in Spain". Biores. Technol. 77, 197-200, 2001.

[14] George, E. F., Puttok, D. J. M., and George, H. J., "The Constituent of culture media, Plant culture media. Comment art and analysis", 2, $348-$ 350,1998

[15] G.Y.Jayasinghe, Y.Tokashiki and M.Kitou "Use of synthetic soil aggregates as a containerized growth medium component to substitute peat in the ornamental plant production". Archives of Agronomy and Soil Science. 56(2), 183-199, 2010.

[16] GY Jayasinghe, Y Tokashiki, M Kitou and K Kinjo “ Effect of synthetic soil aggregates as a soil ameliorant to enhance properties of problematic gray ("Jahgaru") soils in Okinawa, Japan". Communications in soil science and plant analysis. 41 (5), 649-664, 2010

[17] KB Dassanayake, GY Jayasinghe, A Surapaneni and C Hetherington " A review on alum sludge reuse with special reference to agricultural applications and future challenges. Waste Management 38, 321-335, 2015.

[18] Davidson, H., Mecklenburg, R., and Pereson, C., "Nursery management administration and culture", 3, 546-567, 1994.

[19] GY Jayasinghe, Y Tokashiki and M Kitou " Evaluation of coal fly ashbased synthetic aggregates as a soil ameliorant for the low productive acidic red soil. Water, air, and soil pollution 204 (1-4), 29-41, 2009.

[20] GY Jayasinghe "Synthetic soil aggregates as a potting medium for ornamental plant production". Journal of plant nutrition 35 (10), 1441 1456, 2012. 